distribution

\title{
Marital status distribution of the UK military, does it differ from the general population?
}

\section{Keeling, M., Wessely, S. \& Fear, N.T.}

Accepted by Military Behavioural Health June 2016

\section{Abstract}

UK media suggest UK military personnel have high divorce rates; to date, these claims are not substantiated. Marital status distribution of the general population and military were compared using data from the Office for National Statistics marital projections (2008) and a military cohort study (2007 - 2009), respectively. Data from the military cohort study was collected via questionnaire with a response rate of $56 \%$ for the overall cohort questionnaire and $99.5 \%$ for the martial status question. Overall, military personnel (59.4\%) were more likely to be married than the general population (49.3\%) and less likely to be divorced (3.7\%) than the general population $(10.0 \%)$. Military females and military personnel married under 30 years of age are more likely to report divorce. Military welfare services might target these groups with programs assisting marital relationships.

Key Words: Marital Status; Military personnel; Divorce; Marriage; General population 
distribution

\section{Marital status distribution of the UK military, does it differ from the general population?}

The UK media have reported anecdotally that the divorce rates of military personnel have risen over time (BBC News, 2000). However, to date there has been no research from the UK to support these claims. Research from the US indicates that divorce rates amongst US military personnel are comparable to civilians (Karney \& Crown, 2007; Karney, Loughran, \& Pollard, 2012; McCone \& O'Donnell, 2006). Despite this research evidence, $\mathrm{n}$ the US media have continued to raise concern; moreover, spouses of military personnel are also concerned (Karney et al., 2012). Pollard et al. suggest that spouses' concerns have grown from beliefs that military families are more vulnerable than comparable civilians, however this is not substantiated by US research.

Since military operations began in Iraq (2003) and Afghanistan (2001), there have been increased demands placed on UK military personnel (Rona et al., 2014). UK research suggests that marital difficulties could ensue as a consequence of military deployments in those who deploy for more than 13 months in a three year period (Rona et al., 2014). Other factors found to be associated with relationship difficulties among UK military personnel include childhood adversity, lack of support, and financial difficulties (Keeling, Wessely, Dandeker, Jones, \& Fear, 2015), things that are likely to impact relationships regardless of military service. In the US, concern has been raised about increased marital difficulties amongst military personnel, however, these concerns are not supported by divorce figures (Karney \& Crown, 2007). Research does suggest that negative relationships with spouses can lead to military personnel developing mental health difficulties which can affect their ability to complete their job and discourages them from re-enlisting (Hoge, Castro, \& Eaton, 2006). In the UK, research has highlighted the importance of personal relationships and contact with 
distribution

family and friends in providing support to military personnel (Greene, Buckman, Dandeker, \& Greenberg, 2010).

Research from the US that has compared differences between the rates of marriage and divorce between the military and general population indicates that US military personnel are more likely to be married (Cadigan, 2000; Karney et al., 2012) and marry at younger ages (Adler-Baeder, Pittman, \& Taylor, 2006; Hogan \& Seifert, 2010; Karney \& Crown, 2007; Lundquist, 2007) than age matched civilians. It is proposed that younger age at marriage is more common in the military due to job and financial security (Cadigan, 2000; Lundquist, 2007). Moreover, benefits for married military personnel, such as subsidised housing and being part of a supportive environment, may lead to marriage happening prematurely or even accelerating marriages in partnerships that might have otherwise dissolved (Cadigan, 2000; Karney \& Crown, 2007; Lundquist, 2007). Lundquist (2007), however, found that 23 to 27 year old enlisted personnel (in the US enlisted personnel are all ranks below commissioned officer) are more likely to divorce than comparable civilians, even after controlling for demographic, religious, socioeconomic, and attitudinal factors. Hogan and Seifert (2010) found that active duty Armed Forces members who marry aged between 23 25 years have higher divorce rates compared to those who have been married but not served on active duty.

Key differences exist between the US and UK military that may impact marital relationships, for example US operational deployments tend to be longer than UK operational deployments (approximately 12 months compared to six months). To date, in the UK, the marital status distribution of the UK military has not been compared with the marital status distribution of the general population. There is a clear need to do so to understand if the claims made by the media are correct and to better understand the 
distribution

marital relationships of the UK military in order to provide appropriate support to military personnel and their families. This paper compares the marital status distribution of the UK military with the general population of England and Wales. Based on research from the US, it is hypothesised that compared to civilians:

1. A larger proportion of UK military personnel will be married compared to the general population; this will be most evident in the under 30 years olds

2. Despite the larger proportion of married military personnel, in comparison to the general population, a larger proportion of UK military personnel under 30 years of age will be divorced.

\section{Method}

\section{Data Source: Military data}

The King's Centre for Military Health Research (KCMHR) completed a cohort study of a representative sample of the UK Armed Forces comprising of two phases (Fear et al., 2010; Hotopf et al., 2006). Phase 1 compared UK Armed Forces personnel deployed to Iraq between 18 January and 28 April 2003 (the TELIC cohort - TELIC is the UK military codename for the 2003-2009 conflict in Iraq), with serving personnel who were not deployed to Iraq at this time (the 'Era' cohort). Sampling was stratified by Service (Naval Services, Army or Royal Air Force) and enlistment type (regular or reserve - voluntary part time personnel who (may) have civilian jobs as well); reserves were oversampled (2:1). Data were collected between June 2004 and March 2006 with an overall response rate of 58.7\% $(n=10272)$ (Hotopf et al., 2006). Non-response was mainly due to difficulties contacting personnel as a result of training, deployments or being posted to a new location (Iversen, Liddell, Fear, Hotopf, \& Wessely, 2006). There 
distribution

was no evidence of response bias in terms of health outcomes or fitness for deployment (Tate et al., 2006).

Participants from phase 1 were asked to participate at phase 2. Phase 2 also included two further samples. The HERRICK sample (the name of operational tours to Afghanistan) was recruited to represent the UK's expanding involvement in Afghanistan and, the replenishment sample to represent those who had joined the military since phase 1 . Phase 2 data were collected between November 2007 and September 2009 using self-completion questionnaires which were sent to potential participants. The response rate for phase 2 was $56 \%(n=9984)$ (Fear et al., 2010).

\section{Data source: England and Wales general population}

The ONS data are available for people aged 16 years and over who lived in England and Wales, mid-2008 $(\mathrm{n}=34,402,000)$ and provided marital status distribution by age group. The data are derived from statistics on marriage, divorce, and death registrations collected through administrative sources, maintained by the General Register Office (GRO) and the Ministry of Justice (MoJ) (Office for National Statistics, 2011). Data from the adhoc output Principal Marital projection datasheets units v2, from the Statistical Bulletin: Marital status population projections, 2008based (Office for National Statistics, 2010) were used as this provided data by single year of age (from 16 years), allowing the extraction of the data for 18 to 64 year olds.

\section{Measures}

In the KCMHR military cohort study, marital status was assessed using a seven option question that asked, are you: married; living with partner; in a long term relationship; single and not in a long term relationship; separated; divorced; or 
distribution

widowed. Principal Marital projection datasheets units v2, from the Statistical Bulletin: Marital status population projections, 2008-based (Office for National Statistics, 2010) data used marital status categories: never married, married, divorced, or widowed; those who were separated but still legally married were categorised, by ONS, in the married group. To make comparisons between the ONS and KCMHR data, the KCMHR marital status categories were categorised to replicate the ONS marital status categories (figure 1).

\section{Insert figure 1 here}

\section{Study samples}

Military: Only data from phase 2 of the cohort study was used for the purpose of this study. Of the 9984 participants from phase 2 of the KCMHR cohort study, 9934 (99.5\%) provided marital status information and were included in this comparison. Of these, 8752 (88.1\%) were male and 1182 (11.9\%) were female. This sample includes regular and reserve UK military personnel and those who were serving and had left service at the time of questionnaire completion.

England and Wales general population: Extracting marital status for 18 to 64 year olds from the ONS data created a sample of 33,981,858 individuals. Of these, $16,962,772$ (49.9\%) were male and 17,019,086 (50.1\%) female.

\section{Data analysis}

Sample weights for the military data were created to reflect the inverse probability of a participant from a specific subpopulation and specific engagement type 
distribution

(regular or reserve) being sampled. Response weights were also created to account for non-response. Response weights were defined as the inverse probability of responding once sampled and driven by factors shown to empirically predict response (gender, rank, age and sample). Based on the assumption that the data are missing at random and that the observed variables modelled to drive non-response were correctly identified, the weighted analyses proved valid results. A combined weight was generated by multiplying the sample and response weights (Fear et al., 2010).

Weighted percentages were calculated for the military sample and compared to the ONS percentages. To achieve the most meaningful comparison, marital status was investigated by age group (comparable between each sample) (18-29, 30-44, and 4564 years) and gender. Percentages and total numbers are presented for both military and general population samples. 95\% confidence intervals are also presented for the military sample due to the relatively smaller sample size. Due to type of data available from ONS, statistical analysis of the difference in prevalence between military sample and ONS percentages was not useful.

\section{Ethical approval}

The KCMHR cohort study received full ethical approval both from the MoD Research Ethics Committee 0732/117 and King's College Hospital Research Ethics Committee (NHS REC reference: 07/Q0703/36).

\section{Results}

Overall, military personnel were more likely to be married and less likely to be divorced compared to the general population of England and Wales (Table 1). The 
distribution

higher proportion of marriage in the military is most notable in the 18 to 29 years group. Although overall the proportion of divorce is lower compared to the general population, in the 18 - 29 years group the percentage of military personnel who are divorced is higher, however, this difference is small. These results support the hypotheses of this study. The prevalence of being widowed in both the general population and military population is low, however, lower in the military sample. This may be due to difference in the samples as the military sample has fewer participants in the older age groups (table 1).

\section{Insert table one here}

Comparisons stratified by gender show that in contrast to the total sample, marital status distribution of males is similar to that of the overall sample (table 2). Examining female military personnel only, indicates that they have a higher prevalence of never being married compared to females in the general population (table 3). This is consistent across all ages except in 18-29 year olds, and is most notable in the 45 to 65 years age group. Consistent with the total and male samples, female military personnel are less likely to be divorced compared to the general population, except in 18 to 29 year olds where military females are more likely to be divorced. The difference in prevalence of divorce between females in the military and those in the general population aged 18 to 29 years is larger than in the total and male samples, it is, however, still small.

Insert tables two and three here 
distribution

\section{Discussion}

This paper provides the first comparison of military and general population marital status distribution in the UK. Consistent with hypothesis 1, military personnel are more likely to be married, especially those under the age of 30 years compared to the general population. Hypothesis 2 is also supported as military personnel under the age of 30 years are more likely to be divorced, compared to the general population, however, this increase is small. Over the age of 30 years old, military personnel are less likely to be divorced compared to the general population. Female military personnel are more likely to have never been married, except for 18-29 years who are more likely to be married, compared to females in the general population. These results are consistent with existing literature from the US indicating that compared to civilians, military personnel are more likely to be married, marry at younger ages, divorce at younger ages, and military females are more likely to have difficulties forming and maintaining romantic relationships (Adler-Baeder et al., 2006; Cadigan, 2000; Karney et al., 2012).

The increased proportion of marriage in young military personnel, compared to the general population, is likely to be attributable to the job and financial security provided by a military career (Kelty \& Segal, 2013). Literature from the general population shows that financial and job security is perceived as being important in decisions to marry (Smock, Manning, \& Porter, 2005). In the US, it is reported that the military offers young junior enlisted personnel higher pay rates and better benefits than other jobs available to age matched non-serving individuals (Kelty \& Segal, 2013). Consequently, a military career may afford young personnel financial and job security which could inform decisions to marry. 
distribution

Further to financial and job security having the potential to impact decisions to get married, benefits available to married military personnel in the UK may be attributable to the higher prevalence of marriage and the lower prevalence of divorce in the military compared to the general population. These benefits include entitlement to subsidised housing normally on or near the military base ("Defence Infrastructure Organisation: Service Family Accommodation (SFA)," 2013), subsidised boarding school places (Harvey, 2011), and in the event that a serving military member dies, the married spouse is entitled to the war widower pension; unmarried partners are not entitled to this compensation ("War Widow(er) Pension," 2013). Dandeker, Eversden, Birtles, and Wessely (2013) found that many wives of UK Armed Forces personnel reported "perks" that helped moderate the impact of military life, including tax breaks, quality of living, subsidised schooling, and improved social status. They also found that job stability, financial security, and a good pension at the end of service enhanced quality of life (Dandeker et al., 2013). These "perks" might help maintain relationship stability for military personnel.

Similar or lower rates of divorce in the military compared to the general population are reported in the US (Burland \& Lundquist, 2013; Karney et al., 2012). US literature supports the idea that the support, benefits and compensations provided by the military, for married personnel, increase stability in marital relationships (Burland \& Lundquist, 2013; Karney \& Crown, 2011; Karney et al., 2012). Social exchange theory (Thibaut \& Kelley, 1959) stipulates that decisions to start, continue and end relationships are based on the couple involved weighing up the perceived rewards and costs. Relationships are formed when both partners perceive the possible outcomes to be better than any alternatives (Thibaut \& Kelley, 1959). Karney and Crown (2007) suggest social exchange theory can help understand military marriages in terms of a 
distribution

cost/benefits process where potential hardships are compensated for by benefits that strengthen and stabilise the relationship. Burland and Lundquist (2013) report that, there is a premium for US soldiers from disadvantaged backgrounds who in the civilian world would have been more vulnerable to marital dissolution without the financial and support benefits received as part of their military career. Based on social exchange theory, continuation of a relationship may be motivated by the material and supportive gains rather than satisfaction and happiness with the relationship.

Our results indicate that there were proportionally more divorced 18 to 29 year olds in the military compared to the general population. This is consistent with research indicating that marriage at a younger age is associated with marital instability (Burland \& Lundquist, 2013; Karney \& Crown, 2011; McCone \& O'Donnell, 2006; Wilson \& Stuchbury, 2010). Lundquist (2007) suggests that the increased divorce rates in younger military personnel in the US could be a consequence of the stress of military life, particularly in the context of younger less experienced personnel and newer marital bonds that are likely to be less stable.

Military females are more likely to be never married then females in the general population. This is consistent with findings from the US (Adler-Baeder et al., 2006; Karney \& Crown, 2011; Karney \& Crown, 2007; Karney et al., 2012; Segal \& Segal, 2004). Adler-Baeder et al. (2006) compared the marital status of females in the military and general population and found that military females were less likely to be married, more likely to be divorced, and less likely to remarry post-divorce, compared to civilian females. They suggested that this direct comparison is misleading as it does not consider differences in employment status. Comparisons with civilian career women and female military personnel showed little difference by marital status. Adler-Baeder et al. (2006) suggest that this is due to the increased role (marriage/work) conflict for 
distribution

career women, which may also be true for military women. This is consistent with Kelty and Segal (2013) who, based on their research investigating gender differences of marital status within the military, propose that military service is more compatible with the husband/father role, than with the wife/mother role. Breen and Cooke (2005) suggest that relationships where women have higher labour force participation are likely to have greater marital instability, possibly due to the women's decreased need for the husband's economic production or the competition for occupational status within the relationship.

\section{Strengths and Limitations}

The main strength of this research is the use of a large representative sample of the UK Armed Forces. The main limitation of this study is that it categorises co-habiting or in long-term relationships in the never married category along with singles. This categorisation should be considered when interpreting the results. Moreover, marital status categories include those who are remarried in the married category. Including those who are remarried within the married category could over emphasis marital stability in either group.

Armed Forces personnel were included in the ONS data, however, they only make up 1.5\% of the England and Wales population (Office For National Statistics, 2013). A further consideration of the UK military sample is the potential for bias due to the main reasons for non-response of the cohort questionnaire (e.g. personnel being on training, deployments or being posted to a new location) are all factors that could be considered as associated with additional stressors for marital relationships.

Consideration should be given to the differences in marital status response categories between the ONS general population data and the KCMHR UK military data. 
distribution

As stated in the methods section response categories in the military data were recategorised in order to attempt to closely replicate the martial status items in the ONS data. The difference in these categories should however, be considered when interpreting results as they may not have the exact same meaning, especially the "never married" category.

Analysis of the statistical significance of the difference between marital status distributions in each group was not possible due to the nature of the two data sets. However, the proportions presented allow for a comparison which adds to the current literature where no such investigation has been previously conducted.

\section{Implications}

This research indicates that young military personnel are more likely to be married. Awareness of this amongst military welfare services could improve support for young married couples who might benefit from additional relationship advice.

This comparison suggests that female military personnel may have challenges forming and maintaining romantic relationships compared to females in the general population. Being in the military, for females, appears not to be conducive to successful relationships where role conflict between family and work are likely to be increased, compared to males. Further research investigating the work/family conflict experienced by females in the military might be beneficial to help inform policy for how to lessen the impact of such work/life balance challenges.

\section{Conclusion}

UK media and colloquial beliefs present an image of the UK military as being a group with troubled marriages marked by high divorce rates. A comparison of the 
distribution

distribution of marital status between the general population and the military in the UK indicates that overall military personnel are in fact more likely to be married and less likely to be divorced. Military females and military personnel who marry under the age of 30 years old are, however, more likely to experience marital dissolution compared to the general population.

\section{References}

Adler-Baeder, F., Pittman, J. F., \& Taylor, L. (2006). The Prevalence of Marital Transitions in Military Families. Journal of Divorce and Remarriage, 44, 15.

BBC News (Writer). (2000). Divorce in Armed Forces 'Rising'. In.

Breen, R., \& Cooke, L. P. (2005). The Persistence of the Gendered Division of Domestic Labour. European Sociological Review, 21(1), 15.

Burland, D., \& Lundquist, J. H. (2013). The Best Years of Our Lives: Military Service and Family Relationships - A Life-Course Perspective. In J. M. Wilmoth \& A. S. London (Eds.), Life-Course Perspectives on Military Service. New York: Routledge.

Cadigan, J. (2000). Family Status of Enlisted Personnel. Washington DC: Congressional Budget Office.

Dandeker, C., Eversden, C., Birtles, C., \& Wessely, S. (2013). The British Military Family: The experiences of British Army wives before, during and after deployment, their satisfaction with military life and use of support networks. In G. Bowen, R. Moelker, \& P. Manigart (Eds.), Military Families on Mission: Comparative Perspectives: Routledge.

Defence Infrastructure Organisation: Service Family Accommodation (SFA). (2013). Retrieved from https:www.gov.uk/defence-infrastructure-organisation-servicefamily-accommodation

Fear, N. T., Jones, M., Murphy, D., Hull, L., Iversen, A., Coker, B., . . Wessely, S. (2010). What are the consequences of deployment to Iraq and Afghanistan on the mental health of the UK armed forces? A Cohort Study. The Lancet, 375, 1783 1797.

Greene, T., Buckman, J., Dandeker, C., \& Greenberg, N. (2010). How communication with families can both help and hinder service members' mental health and occupational effectiveness on deployment. Military Medicine, 175, 745-749. 
distribution

Harvey, N. (2011). Announcement Review of Continuity of Education Allowance Retrieved from https://www.gov.ul.government/news/review-of-continuity-ofeducation-allowance-concludes

Hogan, P. F., \& Seifert, R. (2010). Marriage and the Military: Evidence that those who Serve Marry Earlier and Divorce Earlier. Armed Forces \& Society, 36, 18.

Hoge, C. W., Castro, C. A., \& Eaton, K. M. (2006). Impact of combat duty in Iraq and Afghanistan on family functioning: Findings from the Walter Reed Army Institute of Research Land Combat Study. Human dimensions in military operations Military Leaders' strategies for addressing stress and psychological support, Meeting proceedings(paper 5), 5-1 - 5-6.

Hotopf, M., Hull, L., Fear, N. T., Browne, T., Horn, O., Iverson, A., . . W Wessely, S. (2006). The Health of UK Military Personnel who Deployed to the 2003 Iraq War: a Cohort Study. The Lancet, 367, 1731 - 1740.

Iversen, A., Liddell, K., Fear, N., Hotopf , M., \& Wessely, S. (2006). Consent, confidentiality, and the Data Protection Act. British Medical Journal, 332, 165169.

Karney, B. R., \& Crown, J. R. (2011). Does deployment keep military marriages together or break them apart? Evidence from Afghanistan and Iraq. In S. Wadsworth MacDermid \& D. Riggs (Eds.), Risk and Resilience in U.S. Military families (pp. 23-45): Springer Scirence+Business Media.

Karney, B. R., \& Crown, J. S. (2007). Families under stress: An assessment of data, theory, and research on marriage and divorce in the military. National Defence Research Institute; RAND corporation.

Karney, B. R., Loughran, D. S., \& Pollard, M. S. (2012). Comparing Marital Status and Divorce Status in Civilian and Military Populations. Journal of Family Issues. doi:10.1177/0192513x12439690

Keeling, M., Wessely, S., Dandeker, C., Jones, N., \& Fear, N. T. (2015). Relationship Difficulties Among U.K. Military Personnel: Impact of Sociodemographic, Military, and Deployment-Related Factors. Marriage \& Family Review, 51(3), 275303. doi:10.1080/01494929.2015.1031425

Kelty, R., \& Segal, D. R. (2013). The Military as a Transforming Influence: Integration into or Isolation from Normal Adult Roles? . In J. M. Wilmoth \& A. S. London (Eds.), Life-Course Perspectives on Military Service. New York: Routledge.

Lundquist, J. H. (2007). A Comparison Of Civilian And Enlisted Divorce Rates During The Early All Volunteer Force. Journal of Political and Military Sociology, 35.

McCone, D., \& O'Donnell, K. (2006). Marriage and Divorce Trends for Graduates of the U.S. Air Force Academy. Military Psychology, 18(1), 14. 
distribution

Office for National Statistics. (2010). Statistical Bulletin: Marital Status Population Projections, 2008 Based. Retrieved from

Office for National Statistics. (2011). Information Paper: Quality and Methodology Information for Population Estimates by Marital status. Cardiff: Office for National Statistics.

Office For National Statistics. (2013). Families and Households in England and Wales 2011. Retrieved from

Rona, R., Jones, M., Keeling, M., Hull, L., Wessely, S., \& Fear, N. T. (2014). Mental health consequences of overstretch in the UK Armed Forces, 2007-09: a population-based cohort study. Lancet Psychiatry. doi:10.1016/S22150366(14)00062-5.

Segal, D. R., \& Segal, M. W. (2004). America's Military Population. Population Bulletin, 59(4).

Smock, P. J., Manning, W. D., \& Porter, M. (2005). "Everything's There Except the Money": How Money Shapes Decisions to Marry Among Cohabitors. Journal of Marriage and Family, 67(16), 680.

Tate, A. R., Jones, M., Hull, L., Fear, N. T., Rona, R., Wessely, S., \& Hotopf ' M. (2006). How many mailouts? Could attempts to increase the response rate in the Iraq war cohort study be counterproductive? BMC Medical Research Methodology, 7, 51.

Thibaut, J. W., \& Kelley, H. H. (1959). The Social Psychology of Groups. New York: Wiley.

War Widow(er) Pension. (2013). Retrieved from https://www.gov.uk/war-widow-pension

Wilson, B., \& Stuchbury, R. (2010). Do Partnerships Last? Comparing Marriage and Cohabitation Using Longitudinal Census Data. Population Trends, 139, 24. 
distribution

$\left.\begin{array}{lll}\text { Marital Status } & \mathbf{N} & \mathbf{\%} \\ \begin{array}{l}\text { Co-habiting } \\ \begin{array}{l}\text { Long term } \\ \text { relationship }\end{array}\end{array} & 1142 & 11.4 \% \\ \text { Single } & 1268 & 10.8 \% \\ \text { Married } & 5171 & 14.5 \%\end{array}\right\} \begin{aligned} & \text { Marital } \\ & \text { Status } \\ & \text { Separated }\end{aligned}$

Figure 1 KCMHR military data original marital status response categories collapsed to represent the ONS marital status response categories 
Table 1 General population and military sample marital status comparison by age group

\begin{tabular}{|c|c|c|c|c|c|c|c|c|c|c|}
\hline \multirow{2}{*}{$\begin{array}{l}\text { Age (in } \\
\text { years) }\end{array}$} & \multicolumn{2}{|c|}{ Total } & \multicolumn{2}{|c|}{ Never Married } & \multicolumn{2}{|c|}{ Married } & \multicolumn{2}{|c|}{ Divorced } & \multicolumn{2}{|c|}{ Widowed } \\
\hline & $\begin{array}{l}\text { General } \\
\% \text { (n) }\end{array}$ & $\begin{array}{c}\text { Militar } \\
y \\
\%(n)\end{array}$ & $\begin{array}{c}\text { General } \\
\% \text { (n) }\end{array}$ & $\begin{array}{c}\text { Military } \\
\%(95 \% \mathrm{CI} / \mathrm{n})\end{array}$ & $\begin{array}{c}\text { General } \\
\% \text { (n) }\end{array}$ & $\begin{array}{c}\text { Military } \\
\%(95 \% \mathrm{CI} / \mathrm{n})\end{array}$ & $\begin{array}{c}\text { General } \\
\% \text { (n) }\end{array}$ & $\begin{array}{c}\text { Military } \\
\%(95 \% / C I / n)\end{array}$ & $\begin{array}{c}\text { General } \\
\% \text { (n) }\end{array}$ & $\begin{array}{c}\text { Military } \\
\% \\
(95 \% / C I / n) \\
\end{array}$ \\
\hline Total & $\begin{array}{c}100 \\
(33,981,858)\end{array}$ & $\begin{array}{c}100 \\
(9934)\end{array}$ & $\begin{array}{c}39.3 \\
(13,340,595)\end{array}$ & $\begin{array}{c}36.8 \\
(35.7-37.6) \\
(4124)\end{array}$ & $\begin{array}{c}49.3 \\
(16,755,966)\end{array}$ & $\begin{array}{c}59.4 \\
(58.4-60.3) \\
(5449)\end{array}$ & $\begin{array}{c}10.0 \\
(3,385,748)\end{array}$ & $\begin{array}{c}3.7 \\
(3.3-4.1) \\
(345)\end{array}$ & $\begin{array}{c}1.5 \\
(499,549)\end{array}$ & $\begin{array}{c}0.1 \\
(<0.01-0.2) \\
(16)\end{array}$ \\
\hline $18-29$ & $\begin{array}{c}25.9 \\
(8,801,767)\end{array}$ & $\begin{array}{c}36.6 \\
(3636)\end{array}$ & $\begin{array}{c}87.8 \\
(7,724,119)\end{array}$ & $\begin{array}{c}69.0 \\
(67.5-70.5) \\
(2668)\end{array}$ & $\begin{array}{c}11.4 \\
(1,001,539)\end{array}$ & $\begin{array}{c}29.6 \\
(28.1-31.1) \\
(925)\end{array}$ & $\begin{array}{c}0.8 \\
(71,110)\end{array}$ & $\begin{array}{c}1.3 \\
(0.9-1.7) \\
(41)\end{array}$ & $\begin{array}{c}0.1 \\
(4,999)\end{array}$ & $\begin{array}{c}<0.1 \\
(-) \\
(2)\end{array}$ \\
\hline $30-44$ & $\begin{array}{c}34.0 \\
(11,542,299)\end{array}$ & $\begin{array}{c}48.6 \\
(4826)\end{array}$ & $\begin{array}{c}35.4 \\
(4,086,148)\end{array}$ & $\begin{array}{c}24.0 \\
(22.8-25.2) \\
(1264)\end{array}$ & $\begin{array}{c}54.4 \\
(6,277,970)\end{array}$ & $\begin{array}{c}71.5 \\
(70.2-72.8) \\
(3358)\end{array}$ & $\begin{array}{c}9.8 \\
(1,135,398)\end{array}$ & $\begin{array}{c}4.4 \\
(3.8-5.0) \\
(199)\end{array}$ & $\begin{array}{c}0.4 \\
(42,783)\end{array}$ & $\begin{array}{c}0.1 \\
(0.01-0.2)\end{array}$ \\
\hline $45-64$ & $\begin{array}{c}40.1 \\
(13,637,792)\end{array}$ & $\begin{array}{c}14.8 \\
(1472)\end{array}$ & $\begin{array}{c}11.2 \\
(1,530,328)\end{array}$ & $\begin{array}{c}10.3 \\
(8.7-11.8) \\
(192)\end{array}$ & $\begin{array}{c}69.5 \\
(9,476,457)\end{array}$ & $\begin{array}{c}82.6 \\
(80.7-84.5) \\
(1166)\end{array}$ & $\begin{array}{c}16.0 \\
(2,179,240)\end{array}$ & $\begin{array}{c}6.6 \\
(5.3-7.9) \\
(105)\end{array}$ & $\begin{array}{c}3.3 \\
(451,549)\end{array}$ & $\begin{array}{c}0.5 \\
(0.1-0.8) \\
(9)\end{array}$ \\
\hline
\end{tabular}

NB: Grouping of marital status modified from the military data to fit the available ONS statistics (see methods for details); general population statistics include some military personnel (maximum prevalence in the general population sample 1.5\%); General population data from the Office for National Statistical Bulletin 2008 (Office for National Statistics, 2010). UK military population KCMHR cohort data collected $2007-2009$. 
Table 2 Male general population and military sample marital status comparison by age group

\begin{tabular}{|c|c|c|c|c|c|c|c|c|c|c|}
\hline \multirow{2}{*}{$\begin{array}{l}\text { Age (in } \\
\text { years) }\end{array}$} & \multicolumn{2}{|c|}{ Total } & \multicolumn{2}{|c|}{ Never Married } & \multicolumn{2}{|c|}{ Married } & \multicolumn{2}{|c|}{ Divorced } & \multicolumn{2}{|c|}{ Widowed } \\
\hline & $\begin{array}{l}\text { General } \\
\% \text { (n) }\end{array}$ & $\begin{array}{c}\text { Military } \\
\% \text { (n) }\end{array}$ & $\begin{array}{c}\text { General } \\
\%(/ n)\end{array}$ & $\begin{array}{c}\text { Military } \\
\%(95 \% \text { CI } / n)\end{array}$ & $\begin{array}{c}\text { General } \\
\% \text { (n) }\end{array}$ & $\begin{array}{c}\text { Military } \\
\%(95 \% \mathrm{CI} / \mathrm{n})\end{array}$ & $\begin{array}{c}\text { General } \\
\% \text { (n) }\end{array}$ & $\begin{array}{c}\text { Military } \\
\%(95 \% \text { CI } / n)\end{array}$ & $\begin{array}{c}\text { General } \\
\% \text { (n) }\end{array}$ & $\begin{array}{c}\text { Military } \\
\%(95 \% \text { CI } / n)\end{array}$ \\
\hline Total & $\begin{array}{c}100 \\
(16,962,7 \\
72)\end{array}$ & $\begin{array}{c}100 \\
(8752)\end{array}$ & $\begin{array}{c}42.7 \\
(7,239,177)\end{array}$ & $\begin{array}{c}34.8 \\
(33.8-35.8) \\
(3433)\end{array}$ & $\begin{array}{c}48.0 \\
(8,136,858)\end{array}$ & $\begin{array}{c}61.4 \\
(60.4-62.4) \\
(5018)\end{array}$ & $\begin{array}{c}8.6 \\
(1,460,578 \\
)\end{array}$ & $\begin{array}{c}3.7 \\
(3.3-4.1) \\
(291)\end{array}$ & $\begin{array}{c}0.7 \\
(126,159)\end{array}$ & $\begin{array}{c}0.1 \\
(0.1-0.2) \\
(10)\end{array}$ \\
\hline $18-29$ & $\begin{array}{c}26.5 \\
(4,494,38 \\
6)\end{array}$ & $\begin{array}{c}35.4 \\
(3101)\end{array}$ & $\begin{array}{c}90.7 \\
(4,077,858)\end{array}$ & $\begin{array}{c}69.2 \\
(67.5-70.8) \\
(2,274)\end{array}$ & $\begin{array}{c}8.7 \\
(391,320)\end{array}$ & $\begin{array}{c}29.6 \\
(28.0-31.2) \\
(796)\end{array}$ & $\begin{array}{c}0.5 \\
(23,451)\end{array}$ & $\begin{array}{c}1.1 \\
(0.7-1.5) \\
(30)\end{array}$ & $\begin{array}{c}0.1 \\
(1,757)\end{array}$ & $\begin{array}{c}0.1 \\
(0.01-0.2) \\
(1)\end{array}$ \\
\hline $30-44$ & $\begin{array}{c}33.9 \\
(5,752,05 \\
1)\end{array}$ & $\begin{array}{c}48.9 \\
(4283)\end{array}$ & $\begin{array}{c}39.2 \\
(2,255,065)\end{array}$ & $\begin{array}{c}21.9 \\
(20.7-23.1) \\
(1,010)\end{array}$ & $\begin{array}{c}52.3 \\
(3,010,728)\end{array}$ & $\begin{array}{c}73.7 \\
(72.4-75.0) \\
(3099)\end{array}$ & $\begin{array}{c}8.3 \\
(474,905)\end{array}$ & $\begin{array}{c}4.4 \\
(3.8-5.0) \\
(171)\end{array}$ & $\begin{array}{c}0.2 \\
(11,353)\end{array}$ & $\begin{array}{c}0.5 \\
(0.3-0.7) \\
(3)\end{array}$ \\
\hline $45-64$ & $\begin{array}{c}39.6 \\
(6,716,33 \\
5)\end{array}$ & $\begin{array}{c}15.6 \\
(1368)\end{array}$ & $\begin{array}{c}13.5 \\
(906,254)\end{array}$ & $\begin{array}{c}8.4 \\
(6.9-9.9) \\
(149)\end{array}$ & $\begin{array}{c}70.5 \\
(4,734,810)\end{array}$ & $\begin{array}{c}84.7 \\
(82.8-86.6) \\
(1123)\end{array}$ & $\begin{array}{c}14.3 \\
(962,222)\end{array}$ & $\begin{array}{c}6.7 \\
(5.4-8.0) \\
(90)\end{array}$ & $\begin{array}{c}1.7 \\
(113,049)\end{array}$ & $\begin{array}{c}0.1 \\
(0.1-0.2) \\
(6)\end{array}$ \\
\hline
\end{tabular}

NB: Grouping of marital status modified from the military data to fit the available ONS statistics (see methods for details); general population statistics include some military personnel (maximum prevalence in the general population sample 1.5\%); General population data from the Office for National Statistical Bulletin 2008 (Office for National Statistics, 2010). 
Table 3 Female general population and military sample marital status comparison by age group

\begin{tabular}{|c|c|c|c|c|c|c|c|c|c|c|}
\hline \multirow{2}{*}{$\begin{array}{l}\text { Age (in } \\
\text { years) }\end{array}$} & \multicolumn{2}{|c|}{ Total } & \multicolumn{2}{|c|}{ Never Married } & \multicolumn{2}{|c|}{ Married } & \multicolumn{2}{|c|}{ Divorced } & \multicolumn{2}{|c|}{ Widowed } \\
\hline & $\begin{array}{l}\text { General } \\
\% \text { (n) }\end{array}$ & $\begin{array}{l}\text { Military } \\
\% \text { (n) }\end{array}$ & $\begin{array}{c}\text { General } \\
\% \text { (n) }\end{array}$ & $\begin{array}{c}\text { Military } \\
\%(95 \% \text { CI/n) }\end{array}$ & $\begin{array}{c}\text { General } \\
\%(/ n)\end{array}$ & $\begin{array}{c}\text { Military } \\
\%(95 \% / n)\end{array}$ & $\begin{array}{c}\text { General } \\
\%(/ n)\end{array}$ & $\begin{array}{c}\text { Military } \\
\% \\
(95 \% / C I / n) \\
\end{array}$ & $\begin{array}{c}\text { General } \\
\% \text { (n) }\end{array}$ & $\begin{array}{c}\text { Military } \\
\%(95 \% \mathrm{CI} / \mathrm{n})\end{array}$ \\
\hline Total & $\begin{array}{c}100 \\
(17,019,0 \\
86)\end{array}$ & $\begin{array}{c}100 \\
(1182)\end{array}$ & $\begin{array}{c}35.8 \\
(6,101,418)\end{array}$ & $\begin{array}{c}53.5 \\
(50.7-56.3) \\
(691)\end{array}$ & $\begin{array}{c}50.6 \\
(8,619,108)\end{array}$ & $\begin{array}{c}41.8 \\
(39.0-44.6) \\
(431)\end{array}$ & $\begin{array}{c}11.3 \\
(1,928,170)\end{array}$ & $\begin{array}{c}4.3 \\
(3.1-5.5) \\
(54)\end{array}$ & $\begin{array}{c}2.2 \\
(1,925,170 \\
)\end{array}$ & $\begin{array}{c}0.4 \\
(0.1-0.8) \\
(6)\end{array}$ \\
\hline 18-29 & $\begin{array}{c}25.3 \\
(4,307,38 \\
1)\end{array}$ & $\begin{array}{l}45.3 \\
(535)\end{array}$ & $\begin{array}{c}84.6 \\
(3,646,261)\end{array}$ & $\begin{array}{c}67.8 \\
(63.8-71.8) \\
(394)\end{array}$ & $\begin{array}{c}14.2 \\
(610,219)\end{array}$ & $\begin{array}{c}29.5 \\
(25.6-33.4) \\
(129)\end{array}$ & $\begin{array}{c}1.1 \\
(47,659)\end{array}$ & $\begin{array}{c}2.6 \\
(1.2-4.0) \\
(11)\end{array}$ & $\begin{array}{c}0.1 \\
(3,242)\end{array}$ & $\begin{array}{c}0.1 \\
(0.1-0.4) \\
(1)\end{array}$ \\
\hline $30-44$ & $\begin{array}{c}34.0 \\
(5,790,24 \\
8)\end{array}$ & $\begin{array}{l}45.9 \\
(543)\end{array}$ & $\begin{array}{c}31.6 \\
(1,831,083)\end{array}$ & $\begin{array}{c}43.0 \\
(38.8-47.2) \\
(254)\end{array}$ & $\begin{array}{c}56.4 \\
(3,267,242)\end{array}$ & $\begin{array}{c}51.8 \\
(47.6-56.0) \\
(259)\end{array}$ & $\begin{array}{c}11.4 \\
(660,493)\end{array}$ & $\begin{array}{c}4.8 \\
(3.0-6.60) \\
(28)\end{array}$ & $\begin{array}{c}0.5 \\
(31,430)\end{array}$ & $\begin{array}{c}0.5 \\
(0.01-1.1) \\
(2)\end{array}$ \\
\hline $45-64$ & $\begin{array}{c}40.7 \\
(6,921,45 \\
7)\end{array}$ & $\begin{array}{c}8.8 \\
(104)\end{array}$ & $\begin{array}{c}9.0 \\
(624,074)\end{array}$ & $\begin{array}{c}45.4 \\
(35.8-55.0) \\
(43)\end{array}$ & $\begin{array}{c}68.5 \\
(4,741,647)\end{array}$ & $\begin{array}{c}43.6 \\
(34.1-53.1) \\
(43)\end{array}$ & $\begin{array}{c}17.5 \\
(1,217,018)\end{array}$ & $\begin{array}{c}10.0 \\
(4.23-15.8) \\
(15)\end{array}$ & $\begin{array}{c}4.9 \\
(338,718)\end{array}$ & $\begin{array}{c}1.0 \\
(0.1-2.9) \\
(3)\end{array}$ \\
\hline
\end{tabular}

NB: Grouping of marital status modified from the military data to fit the available ONS statistics (see methods for details); general population statistics include some military personnel (maximum prevalence in the general population sample 1.5\%); General population data from the Office for National Statistical Bulletin 2008 (Office for National Statistics, 2010). 